\title{
Primary primitive neuroectodermal tumor of urinary bladder: a case report and literature review
}

\author{
Yuhai Wu ${ }^{1 \#}$, Hong Ji ${ }^{2 \#}$, Shudong Zhang ${ }^{3}$, Yangyang Zhang ${ }^{4}$, Wei Chu ${ }^{4}$, Yanhui Mei ${ }^{1}$, Wenjie Niu ${ }^{1}$, Bing Zhang ${ }^{5}$ \\ ${ }^{1}$ Department of Urology, Binzhou Medical University Hospital, Binzhou, China; ${ }^{2}$ Department of Pathology, Qilu Hospital (Qingdao), Cheeloo \\ College of Medicine, Shandong University, Qingdao, China; ${ }^{3}$ Department of Psychology, Binzhou Medical University Hospital, Binzhou, China; \\ ${ }^{4}$ Department of Pathology, Binzhou Medical University Hospital, Binzhou, China; ${ }^{5}$ Department of Urology, Qilu Hospital (Qingdao), Cheeloo \\ College of Medicine, Shandong University, Qingdao, China \\ "These authors contributed equally to this work. \\ Correspondence to: Bing Zhang. Department of Urology, Qilu Hospital (Qingdao), Cheeloo College of Medicine, Shandong University, \\ Qingdao 266035, China. Email: urologybzmc@163.com.
}

\begin{abstract}
Primary primitive neuroectodermal tumor (PNET) of the bladder is an extremely rare and highly aggressive neoplasm. We report a case of PNET of the urinary bladder associated with increased serum neuron-specific enolase (NSE) in the presence of relapse and metastasis. A 66-year-old male presented to our department due to painless gross hematuria. Computed tomographic urography (CTU) showed an intraluminal tumor in the anterior bladder wall. Biopsy revealed a malignant small round blue cell tumor. The patient denied radical cystectomy, and partial cystectomy was given together with resection of adjacent peritoneum. The patient was diagnosed with primary bladder PNET after pathological inspection with negative surgical margins. Additionally, he received 6 cycles of chemotherapy using etoposide and cisplatin (EP) regime, and showed recurrence and metastasis afterwards. Disease progression was seen after transurethral resection (TUR) of bladder tumor and radiotherapy. Pelvic and retroperitoneal metastasis triggered bilateral hydronephrosis, and then palliative treatment was given with bilateral percutaneous nephrostomy. Finally, he died 12 months after diagnosis. PNETs are highly aggressive tumors characterized by the expression of MIC2 and neural markers and the presence of EWS-FLI1 translocation. We recommend histologic, immunohistochemical, and cytogenetic analysis in all patients with small round blue cell bladder malignancy in order to rule out other small cell malignancies. Multimodal treatment, including surgery and adjuvant chemotherapy must be initiated. Patients aged $\leq 30$ years underwent complete resection of tumor and standard chemotherapy showed a better prognosis, while those with metastasis, incomplete resection and inadequate response to chemotherapy showed poor prognosis. Moreover, an elevated NSE may indicate a poor prognosis.
\end{abstract}

Keywords: Urinary bladder; primary primitive neuroectodermal tumor (PNET); biopsy; case report

Submitted May 20, 2021. Accepted for publication Sep 22, 2021.

doi: $10.21037 /$ tcr-21-864

View this article at: https://dx.doi.org/10.21037/tcr-21-864

\section{Introduction}

Primitive neuroectodermal tumors (PNETs) are highly aggressive small round blue cell tumors with neuroblastic differentiation that occurs outside the brain, spinal cord and sympathetic nervous system (1). They are assigned to the Ewing family of tumors including Ewing's sarcoma of bone, extraosseous Ewing's sarcoma, PNET, and Askin's tumor (2). These tumors share typical histopathological, immunohistochemical and ultrastructural features, together with the cytogenetic alteration described as $\mathrm{t}(11 ; 22)(\mathrm{q} 24 ; \mathrm{q} 12)$. To our best knowledge, PNET is distinguished from other Ewing family of tumors by overexpressing CD99 and certain neural markers (e.g., Leu-7). It predominantly affects children and adolescents, 
which arises in deep soft tissues, such as kidney, ovary, as well as pancreas (3). The clinical findings of PNETs were not specific, while patients with vesical PNET were aged population with a high tendency of being diagnosed as metastatic diseases. The prognosis was poor even after multimodal therapy, particularly those with primary PNET of the urinary bladder. In this study, we presented a case of primary bladder PNET and reviewed its clinicopathological features, therapeutic strategies and prognostic factors to provide helpful information in the diagnosis and treatment of bladder PNET. We present the following article in accordance with the CARE reporting checklist (available at https://dx.doi.org/10.21037/tcr-21-864).

\section{Case presentation}

A 66-year-old male presented to our department due to painless gross hematuria on September 12, 2016. Physical examination was unremarkable. Urinalysis showed a red blood cell count of $1.1 \times 10^{4}$ per high power field (HPF, reference range, $0-3 / \mathrm{HPF}$ ) and 7 white blood cells per HPF (reference range, $0-5 / \mathrm{HPF}$ ). The other laboratory findings including neuron-specific enolase (NSE) level were within the normal ranges. Computed tomographic urography (CTU) showed an extensive, predominantly intraluminal, irregular bladder tumor $(3.7 \mathrm{~cm} \times 2.5 \mathrm{~cm})$ arising from the anterior wall of the urinary bladder combined with thickening of bladder wall (Figure 1A). There was a vague boundary between bladder wall and the perivesical tissue. Chest computed tomography (CT) and magnetic resonance imaging (MRI) findings of the brain were negative. Cystoscopy revealed a bleeding sessile tumor with focal areas of necrosis at the anterior bladder wall. He denied histories of genetic diseases and other diseases, or a history of smoking and drinking alcohol. The study protocol was approved by the ethics board of Binzhou Medical University Hospital (LW-019). All procedures performed in studies involving human participants were in accordance with the ethical standards of the institutional and/or national research committee(s) and with the Helsinki Declaration (as revised in 2013). Written informed consent was obtained from the patient for publication of this case report and accompanying images. A copy of the written consent was available upon appropriate requests.

Biopsy was performed during cystoscopy inspection. Pathological diagnosis indicated a small round blue malignant neoplasm. Immunohistochemical staining indicated that the tumor cells were diffusely positive for synaptophysin and CD56, and were negative for pan cytokeratin, chromogranin A and leukocyte common antigen. The Ki-67 index was about $80 \%$. The patient underwent partial cystectomy on September 23, 2016 to resect the tumor and the adjacent peritoneum.

Grossly, a polypoidal tumor $(4.3 \mathrm{~cm} \times 4 \mathrm{~cm} \times 3 \mathrm{~cm})$ was presented in the bladder wall with focal necrosis. Macroscopic examination showed a tumor diffusely infiltrated the lamina propria and muscularis propria. The urothelium was infiltrated by tumor cells. Neoplastic cells were arranged in solid sheets and nests. Occasionally, rosette-like structures were noted. The tumor cells were small round blue cells with scant cytoplasm, monotonous round or oval nuclei, with finely dispersed chromatin. The nucleoli were not obvious. Mitotic activity was high and apoptosis was also noted. Necrosis was present in some area. Immunohistochemically, the tumor cells were positive for CD99, CD56, synaptophysin, and Fli-1 (Figure 1B-1G). In contrast, the tumor cells were negative for CK, EMA, vimentin, chromogranin $\mathrm{A}$, myo D1, myogenin, desmin, smooth muscle actin, S-100, CD117, CD34, terminal deoxynucleotidyl transferase, as well as WT-1. About $10 \%$ of the tumor cells were positive for GATA-3. The Ki-67 index was about $80 \%$ (Figure $1 H$ ). The final diagnosis was primary PNET of the bladder.

The patient showed complete response after 6 cycles of chemotherapy using etoposide and cisplatin (EP) regime. Pelvic MRI performed on February 7, 2017 revealed recurrence of the primary bladder tumor. $\mathrm{He}$ showed partial response after transurethral resection (TUR) of bladder tumor and external beam radiotherapy (60 Gy/30 f). The recovery was eventful with serum NSE at a concentration of $40.38 \mathrm{ng} / \mathrm{mL}$ (reference range, 0-16.3 ng/mL). On September 1, 2017, he showed edema in the lower extremities, pain in the lower abdomen and bilateral flank. CT scan demonstrated pelvic and retroperitoneal metastasis, resulting in bilateral ureteral dilation and hydronephrosis. Serum creatinine was higher than the reference range $(142.7 \mu \mathrm{mol} / \mathrm{L}$; reference range, $0-132 \mu \mathrm{mol} / \mathrm{L})$. As he denied chemotherapy and radiotherapy, palliative treatment was given using bilateral percutaneous nephrostomy. Finally, the patient died on October 4, 2017 (Figure 2).

\section{Discussion}

Primary bladder PNET is extremely rare. A comprehensive literature search was carried out for primary bladder 

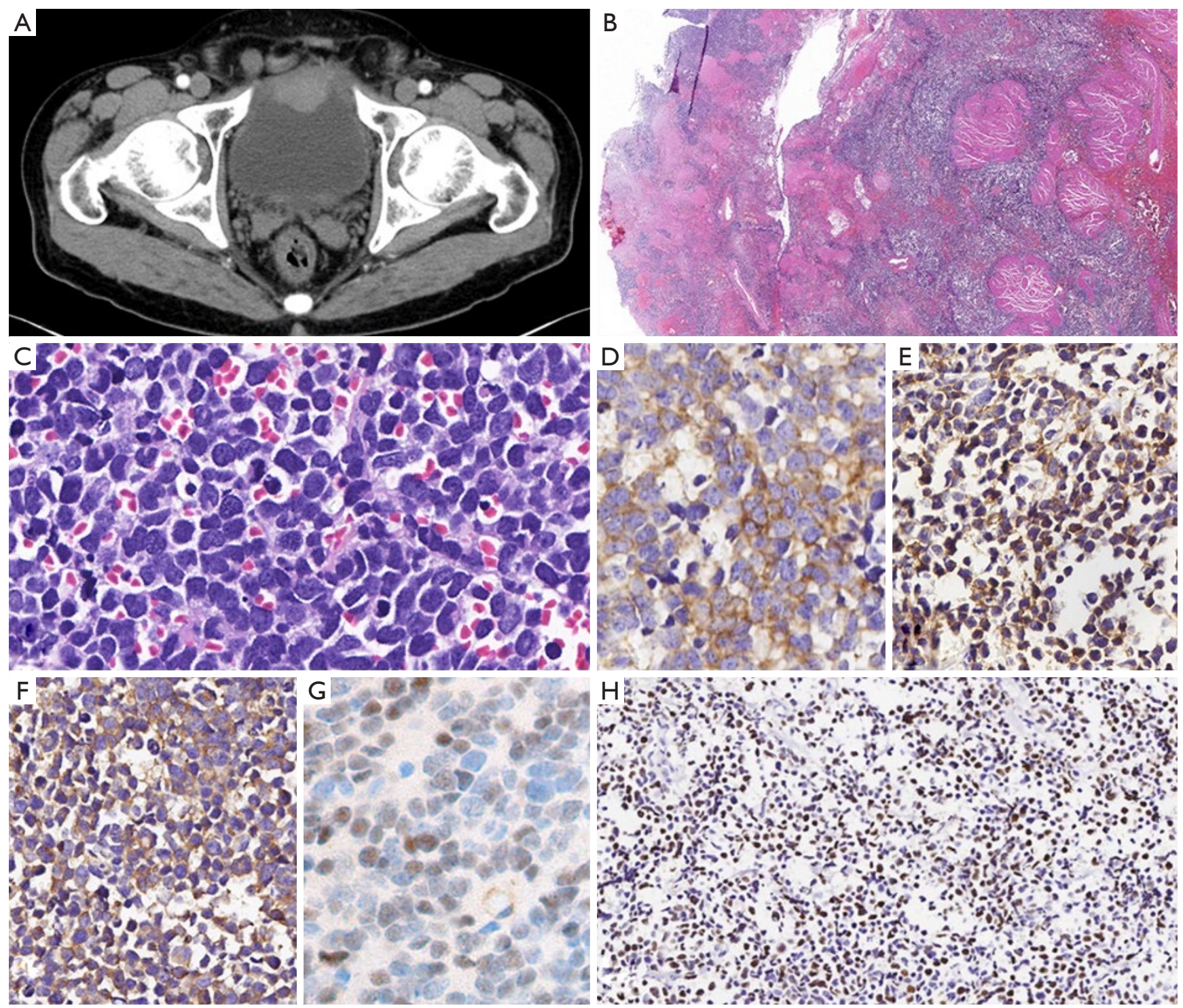

Figure 1 Primary PNET of the bladder. (A) CTU revealed an extensive, intraluminal, irregular mass $(3.7 \mathrm{~cm} \times 2.5 \mathrm{~cm})$ in the anterior wall of the urinary bladder with thickening of the bladder wall. There was undefined plane between the anterior bladder wall and pelvic tissues. (B) Histological findings indicated sheets of small round blue cells infiltrating in the bladder (hematoxylin-eosin staining, $\times 6$ ). (C) The tumor cells were small with scant cytoplasm. The chromatin was fine (hematoxylin-eosin staining, $\times 400)$. (D-H) Immunohistochemical staining of CD99 (Enlivision, ×200), synaptophysin (Enlivision, ×200), CD56 (Enlivision, ×200), fli-1 (Enlivision, ×200) and Ki-67 (Enlivision, $\times 100$ ). PNET, primitive neuroectodermal tumor; CTU, computed tomographic urography.

PNET in PubMed, and a total of 17 English articles were obtained in Table 1 (1,3-18). In total, 18 cases (male: 9; female: 9) with bladder PNET were found including our case. The median age was 47.5 years (10-81 years), which was older than the counterparts with lesion in other sites. All the patients showed no specific symptoms, among which 11 cases presented hematuria and 7 presented lower urinary tract symptoms. Likewise, the physical examination findings were not remarkable. Therefore, diagnosis of bladder PNET was not adequate based on the complaints and physical examination findings. Two patients received chemotherapy for treating solid tumors in femoral muscle and bladder, respectively $(3,4)$. Two patients received chemotherapy for Hodgkin's disease 


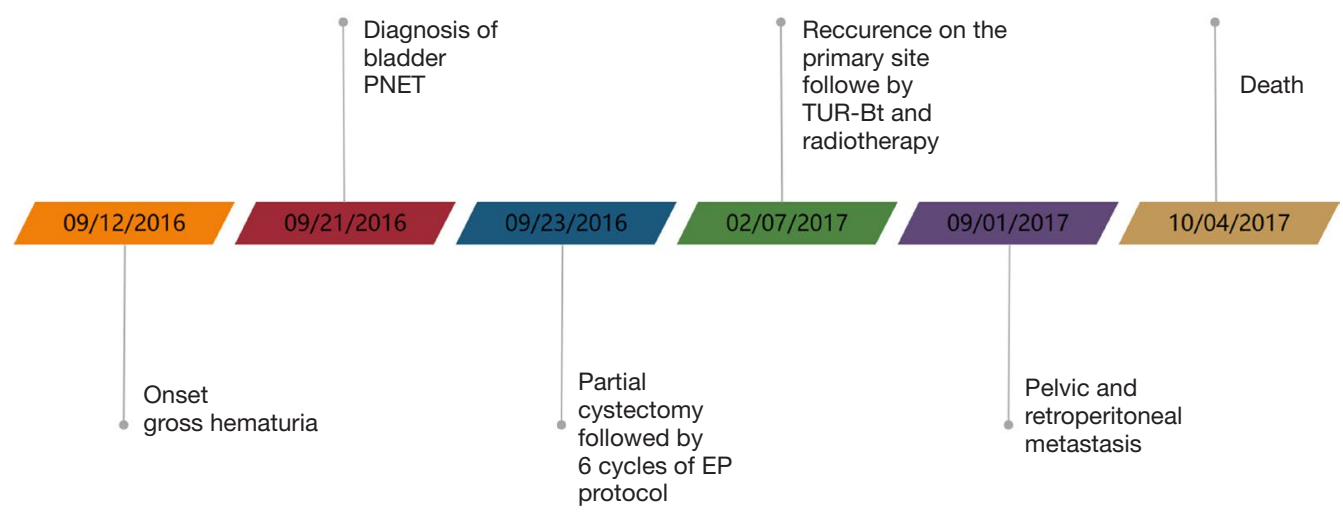

Figure 2 Timeline of the case showed the onset, diagnosis, progression, treatment, and death of the case. PNET, primitive neuroectodermal tumor; EP protocol, etoposide + cisplatin; TUR, transurethral resection.

Table 1 Summary of the clinicopathological features

\begin{tabular}{|c|c|c|c|c|c|c|c|c|c|c|c|c|}
\hline \multirow{2}{*}{ Cases } & \multirow{2}{*}{$\begin{array}{l}\text { Age/ } \\
\text { sex }\end{array}$} & \multirow{2}{*}{ Presentation } & \multirow{2}{*}{$\begin{array}{c}\text { Tumor size } \\
\mathrm{cm}\end{array}$} & \multirow{2}{*}{ Metastasis } & \multicolumn{3}{|c|}{$\begin{array}{l}\text { Immunohistochemical } \\
\text { findings }\end{array}$} & \multirow{2}{*}{$\begin{array}{l}\text { EWS/ } \\
\text { FLI-1 } \\
\text { fusion }\end{array}$} & \multirow{2}{*}{ Operation } & \multirow{2}{*}{ Chemotherapy } & \multirow{2}{*}{ Radiation } & \multirow{2}{*}{$\begin{array}{l}\text { Status in the } \\
\text { last follow-up }\end{array}$} \\
\hline & & & & & CD99 & NSE & S-100 & & & & & \\
\hline $\begin{array}{l}\text { Al } \\
\text { Meshaan } \\
\text { et al. (4) }\end{array}$ & $67 / F$ & $\begin{array}{l}\text { Hematuria, } \\
\text { fever }\end{array}$ & $3 \times 2.5 \times 1$ & None & + & + & + & ND & Partial cystectomy & No & No & $\begin{array}{c}\text { DOCD, } \\
6 \text { months }\end{array}$ \\
\hline $\begin{array}{l}\text { Colecchia } \\
\text { et al. (6) }\end{array}$ & $61 / F$ & $\begin{array}{c}\text { Bilateral } \\
\text { hydronephrosis }\end{array}$ & NA & Pulmonary & + & ND & ND & Yes & NA & NA & No & NA \\
\hline $\begin{array}{l}\text { Desai } \\
\text { et al. (7) }\end{array}$ & $38 / F$ & $\begin{array}{c}\text { Gross } \\
\text { hematuria }\end{array}$ & $12 \times 7 \times 3.5$ & None & + & + & - & ND & $\begin{array}{c}\text { Radical } \\
\text { cystectomy }\end{array}$ & NA & No & NA \\
\hline $\begin{array}{l}\text { Gousse } \\
\text { et al. (8) }\end{array}$ & $15 / F$ & $\begin{array}{c}\text { Gross } \\
\text { hematuria }\end{array}$ & $2 \times 2 \times 3$ & None & + & NA & NA & Yes & $\begin{array}{l}\text { TUR + partial } \\
\text { cystectomy }\end{array}$ & VDC/IE & No & $\begin{array}{l}\text { Alive, NED } \\
18 \text { months }\end{array}$ \\
\hline $\begin{array}{l}\text { Krüger } \\
\text { et al. (9) }\end{array}$ & $81 / \mathrm{M}$ & $\begin{array}{l}\text { Lymphedema, } \\
\text { fatigue, urge } \\
\text { incontinence }\end{array}$ & NA & None & + & + & - & Yes & TUR (palliative) & No & No & $\begin{array}{c}\text { DOD, } \\
2 \text { weeks }\end{array}$ \\
\hline
\end{tabular}

Table 1 (continued) 
Table 1 (continued)

\begin{tabular}{|c|c|c|c|c|c|c|c|c|c|c|c|c|}
\hline \multirow{2}{*}{ Cases } & \multirow{2}{*}{$\begin{array}{l}\text { Age/ } \\
\text { sex }\end{array}$} & \multirow{2}{*}{ Presentation } & \multirow{2}{*}{$\begin{array}{c}\text { Tumor size, } \\
\mathrm{cm}\end{array}$} & \multirow{2}{*}{ Metastasis } & \multicolumn{3}{|c|}{$\begin{array}{l}\text { Immunohistochemical } \\
\text { findings }\end{array}$} & \multirow{2}{*}{$\begin{array}{l}\text { EWS/ } \\
\text { FLI-1 } \\
\text { fusion }\end{array}$} & \multirow{2}{*}{ Operation } & \multirow{2}{*}{ Chemotherapy } & \multirow{2}{*}{ Radiation } & \multirow{2}{*}{$\begin{array}{l}\text { Status in the } \\
\text { last follow-up }\end{array}$} \\
\hline & & & & & CD99 & NSE & $S-100$ & & & & & \\
\hline $\begin{array}{l}\text { Okada } \\
\text { et al. (13) }\end{array}$ & $65 / \mathrm{M}$ & $\begin{array}{c}\text { Gross } \\
\text { hematuria, } \\
\text { dysuria }\end{array}$ & 5 & None & + & ND & - & Yes & Cystectomy & VIDE & Yes & $\begin{array}{l}\text { DOASMAT, } \\
22 \text { months; } \\
\text { relapse, } \\
8 \text { months } \\
\text { later }\end{array}$ \\
\hline $\begin{array}{l}\text { Osone } \\
\text { et al. (14) }\end{array}$ & $16 / \mathrm{M}$ & $\begin{array}{l}\text { Gross } \\
\text { hematuria, } \\
\text { dysuria }\end{array}$ & 1 & None & + & ND & - & Yes & TUR & $\begin{array}{c}\text { Modified P6 } \\
\text { protocol }\end{array}$ & No & $\begin{array}{l}\text { Alive, NED } \\
2 \text { years }\end{array}$ \\
\hline $\begin{array}{l}\text { Sueyoshi } \\
\text { et al. (16) }\end{array}$ & 10/M & $\begin{array}{l}\text { Polyuria, lower } \\
\text { abdominal } \\
\text { swelling }\end{array}$ & $14 \times 13 \times 13$ & None & + & ND & - & Yes & Partial cystectomy & VDC/IE & No & $\begin{array}{l}\text { Alive, NED } \\
11 \text { months }\end{array}$ \\
\hline $\begin{array}{l}\text { Tonyalı et } \\
\text { al. (17) }\end{array}$ & $38 / F$ & $\begin{array}{c}\text { Gross } \\
\text { hematuria }\end{array}$ & $4 \times 2.6 \times 2.5$ & None & + & ND & - & Yes & $\begin{array}{c}\text { Radical } \\
\text { cystectomy }\end{array}$ & VDC/IE & No & $\begin{array}{l}\text { Alive, NED } \\
14 \text { months }\end{array}$ \\
\hline $\begin{array}{l}\text { Zheng et } \\
\text { al. (18) }\end{array}$ & $74 / \mathrm{M}$ & $\begin{array}{l}\text { Hematuria, } \\
\text { frequency, } \\
\text { dysuria }\end{array}$ & NA & $\begin{array}{c}\text { Pelvic } \\
\text { lymph node }\end{array}$ & + & ND & ND & ND & Not described & Modified VAC & No & $\begin{array}{l}\text { DOD, } 4 \\
\text { weeks }\end{array}$ \\
\hline $\begin{array}{l}\text { Current } \\
\text { case }\end{array}$ & $66 / \mathrm{M}$ & $\begin{array}{c}\text { Gross } \\
\text { hematuria }\end{array}$ & $3.7 \times 2.5$ & None & + & ND & - & ND & Partial cystectomy & EP protocol & Yes & DOD, 1 year \\
\hline
\end{tabular}

+/-, the immunohistochemical staining of the tumor cells was positive/negative for certain antigen. M, male; F, female; NA, not available; ND, not done; TUR, transurethral resection; VAC, vincristine + actinomycin D + cyclophosphamide; VDC, vincristine + doxorubicin + cyclophosphamide; $\mathrm{IE}$, ifosfamide + etoposide; EP protocol, etoposide + cisplatin; P6 protocol, courses 1, 2, 3 and 6 consist of vincristine, doxorubicin and cyclophosphamide, courses 4, 5 and 7 consist of ifosfamide and etoposide; NED, no evidence of disease; DOCD, died of cardiac disease; DOD, died of disease; DOPE, died of pulmonary embolism; DOASMAT, died of acute superior mesenteric artery thrombosis.

and acute lymphoblastic leukemia, respectively $(7,14)$. One patient received immunosuppression therapy for renal transplantation (1). Increasing evidence indicated that deranged immunological mechanisms might be risk factors for bladder PNET. Some renal PNET cases showed elevation of lactate dehydrogenase and NSE, especially those with metastasis $(19,20)$. Serum NSE level could be used as a marker to predict the progression of bladder PNET. In this case, the NSE level was in the normal range after the first multimodal therapy in our hospital. However, the NSE was at a higher level even he received the second multimodal therapy in another hospital. No specific signs of PNET were available after utilization of imaging technique, however, MRI and CT provide an assessment of distant metastasis.
The diagnosis of PNET is highly relied on the pathological findings. Histologically, bladder PNET appeared as tumors composed of poorly differentiated small, round and blue cells, which formed rosette-like structures in some cases $(5 / 18)(9,12,15,18)$. Immunohistochemically, CD99 was positive in all cases. NSE, vimentin, S-100 were expressed in $87.5 \%, 77.8 \%$ and $42.9 \%$ of the bladder PNET patients, respectively. The other malignant small, round cell tumors (e.g., small cell neuroendocrine carcinoma, rhabdomyosarcoma, haemotopoietic and lymphoid neoplasm) could be excluded by neural features, together with immunohistochemical staining of cytokeratin, desmin and lymphoid markers. The non-random chromosomal translocation described as $\mathrm{t}(11 ; 22)(\mathrm{q} 24 ; \mathrm{q} 12)$ was detected in all cases (7/7) by fluorescent in situ hybridization or reverse 

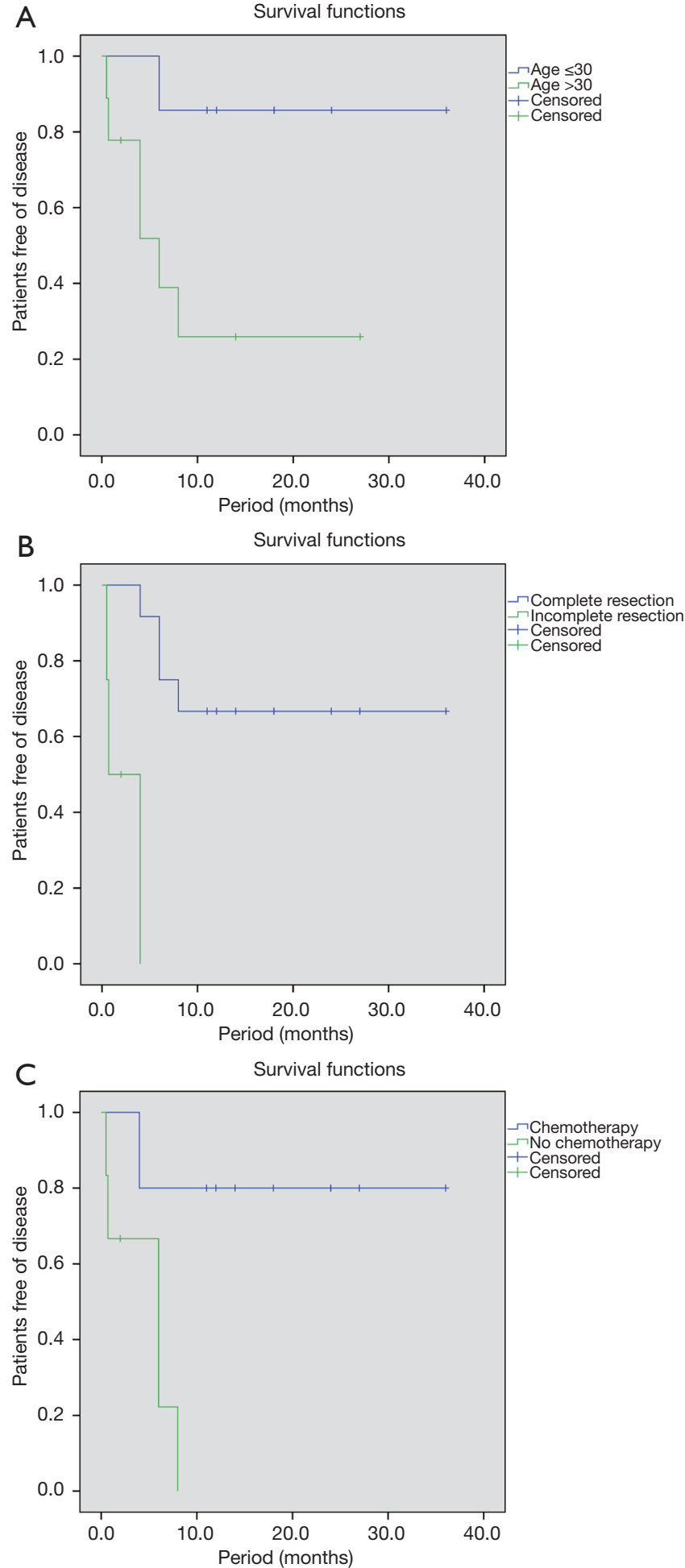

Figure 3 Kaplan-Meier curve assessment of survival as function of age (A), surgery (B) and chemotherapy (C). Kaplan-Meier analysis was performed for 16 patients with clinical data. transcription-polymerase chain reaction, which added clear evidences to the diagnosis of PNET. Other translocations such as $\mathrm{t}(21 ; 22)(\mathrm{q} 22 ; \mathrm{q} 12)$ and/or $\mathrm{t}(7 ; 22)(\mathrm{p} 22 ; \mathrm{q} 12)$ were also reported $(21,22)$.

Primary bladder PNET is highly aggressive and is usually misdiagnosed especially in unusual sites (19). To date, the diagnosis and treatment of bladder PNET is still a challenge for the pathologists and clinicians. In the presence of small round tumor cells expressing neurosecretory markers upon routine histologic tests, the diagnosis of PNETs should be taken into consideration. Immunohistochemical and molecular tests were crucial for the diagnosis.

Multimodal therapy, including complete resection of primary tumor, multi-agent chemotherapy and postoperative radiotherapy, is mandatory due to the occult metastasis even in patients with apparently localized disease. Due to the rarity of primary bladder PNET, the chemotherapy regime was derived from studies on the Ewing's sarcoma, consisted of vincristine, doxorubicin, and cyclophosphamide, alternating with ifosfamide and etoposide (VDE/IE) (23). Eight cases received surgery and standard (neo) adjuvant chemotherapy showed no recurrence in the 11-36 months follow-up periods $(1,5,8,10,11,14,16,17)$. Three cases underwent complete resection of the primary tumors without adjuvant chemotherapy, and the prognosis was poor. One died from cardiac disease 6 months after complete resection (4), and two showed relapse about 6 and 8 months after complete resection $(13,15)$, respectively. Radical cystectomy was denied by our patient. Unfortunately, the patient showed disease progression after partial cystectomy and 6 cycles of EP. Therefore, the prognosis of primary bladder PNET was poor even after multimodal therapy. Notably, Lopez-Beltran and his colleagues (11) reported that there was high expression of CD117 (c-kit) in tumor cells. As a targeted c-kit inhibitor involved in inhibiting proliferation of Ewing tumor cells and sensitizing the apoptotic effects of vincristine and doxorubicin (24), Imatinib was administered together to the patient in their study. Finally, the patient was free of recurrence in the 3-year follow-up.

Kaplan-Meier analysis was performed for the patients with a definitive outcome using SPSS 18.0 software. Patients aged $\leq 30$ years showed a better prognosis compared with those aged $>30$ years (log-rank, $\mathrm{P}=0.021$, Figure $3 A$ ). Complete resection of tumor $(\mathrm{P}=0.001$, Figure $3 B)$ and standard chemotherapy $(\mathrm{P}=0.004$, Figure $3 C)$ were favorable factors for a better prognosis. Metastasis, incomplete resection, and inadequate response to chemotherapy were 
associated with a poor prognosis $(25,26)$. Meanwhile, increased NSE level in the peripheral blood may indicate a poor prognosis. On this basis, we advocated the application of serum NSE level as a routine item for the follow-up of patients with bladder PNET.

In conclusion, primary urinary bladder PNET is extremely rare with highly aggressive features. Notably, patients with bladder PNET were older than those diagnosed in other organs. With non-specific symptoms, bladder PNET was often diagnosed at an advanced stage, which resulted in poor prognosis due to a rapid progression. Therefore, PNET should be considered in the differential diagnosis upon identification of small round blue tumor cells in a bladder neoplasm. Immunohistochemical staining and molecular detection are essential for the final diagnosis. Upon diagnosis of PNET, multimodal therapy, including complete resection of tumor, adjuvant chemotherapy or/and radiotherapy, is mandatory. Targeted therapy can be included in the multimodal protocol of metastatic or chemo-refractory bladder PNET. Patients aged less than 30 years with complete resection of tumor and standard chemotherapy showed better prognosis, while metastasis, incomplete resection and inadequate response to chemotherapy were unfavorable factors. Moreover, an elevated NSE may indicate a poor prognosis among the PNET patients, and further studies are needed to confirm this observation.

\section{Acknowledgments}

Funding: This work was funded by grants from Medical and Health Science and Technology Development Project of Shandong Province (No. 2018WS547, to Bing Zhang; No. 2015WS0494, to Hong Ji), Natural Science Foundation of Shandong Province (No. ZR2020MC068, to Hong Ji).

\section{Footnote}

Reporting Checklist: The authors have completed the CARE reporting checklist. Available at https://dx.doi. org/10.21037/tcr-21-864

Peer Review File: Available at https://dx.doi.org/10.21037/ tcr-21-864

Conflicts of Interest: All authors have completed the ICMJE uniform disclosure form (available at https://dx.doi. org/10.21037/tcr-21-864). The authors have no conflicts of interest to declare.

Ethical Statement: The authors are accountable for all aspects of the work in ensuring that questions related to the accuracy or integrity of any part of the work are appropriately investigated and resolved. The study protocol was approved by the ethics board of Binzhou Medical University Hospital (LW-009). All procedures performed in studies involving human participants were in accordance with the ethical standards of the institutional and/or national research committee(s) and with the Helsinki Declaration (as revised in 2013). Written informed consent was obtained from the patient for publication of this case report and accompanying images. A copy of the written consent is available for review by the editorial office of this journal.

Open Access Statement: This is an Open Access article distributed in accordance with the Creative Commons Attribution-NonCommercial-NoDerivs 4.0 International License (CC BY-NC-ND 4.0), which permits the noncommercial replication and distribution of the article with the strict proviso that no changes or edits are made and the original work is properly cited (including links to both the formal publication through the relevant DOI and the license). See: https://creativecommons.org/licenses/by-nc-nd/4.0/.

\section{References}

1. Banerjee SS, Eyden BP, McVey RJ, et al. Primary peripheral primitive neuroectodermal tumour of urinary bladder. Histopathology 1997;30:486-90.

2. Carpentieri DF, Qualman SJ, Bowen J, et al. Protocol for the examination of specimens from pediatric and adult patients with osseous and extraosseous ewing sarcoma family of tumors, including peripheral primitive neuroectodermal tumor and ewing sarcoma. Arch Pathol Lab Med 2005;129:866-73.

3. Ellinger J, Bastian PJ, Hauser S, et al. Primitive neuroectodermal tumor: rare, highly aggressive differential diagnosis in urologic malignancies. Urology 2006;68:257-62.

4. Al Meshaan MK, Nayef M, Kwaider T, et al. Peripheral primitive neuroectodermal tumor of the urinary bladder in an Arab woman with history of squamous cell carcinoma: a case report. J Med Case Rep 2009;3:6840.

5. Busato WF Jr, Almeida GL, Ogata DC. Primary primitive neuroectodermal tumor of the bladder: histologic and 
clinical features of 9 cases. Clin Genitourin Cancer 2011;9:63-7.

6. Colecchia M, Dagrada GP, Poliani PL, et al. Immunophenotypic and genotypic analysis of a case of primary peripheral primitive neuroectodermal tumour (pPNET) of the urinary bladder. Histopathology 2002;40:108-9.

7. Desai S. Primary primitive neuroectodermal tumour of the urinary bladder. Histopathology 1998;32:477-8.

8. Gousse AE, Roth DR, Popek EJ, et al. Primary Ewing's sarcoma of the bladder associated with an elevated antinuclear antibody titer. J Urol 1997;158:2265-6.

9. Krüger S, Schmidt H, Kausch I, et al. Primitive neuroectodermal tumor (PNET) of the urinary bladder. Pathol Res Pract 2003;199:751-4.

10. Lam CJ, Shayegan B. Complete resection of a primitive neuroectodermal tumour arising in the bladder of a 31-year-old female after neoadjuvant chemotherapy. Can Urol Assoc J 2016;10:E264-7.

11. Lopez-Beltran A, Pérez-Seoane C, Montironi R, et al. Primary primitive neuroectodermal tumour of the urinary bladder: a clinico-pathological study emphasising immunohistochemical, ultrastructural and molecular analyses. J Clin Pathol 2006;59:775-8.

12. Mentzel T, Flaschka J, Mentzel HJ, et al. Primary primitive neuroectodermal tumor of the urinary bladder. Clinicopathologic case report and differential small cell tumor diagnosis of this site. Pathologe 1998;19:154-8.

13. Okada Y, Kamata S, Akashi T, et al. Primitive neuroectodermal tumor/Ewing's sarcoma of the urinary bladder: a case report and its molecular diagnosis. Int J Clin Oncol 2011;16:435-8.

14. Osone S, Hosoi H, Tanaka K, et al. A case of a ewing sarcoma family tumor in the urinary bladder after treatment for acute lymphoblastic leukemia. J Pediatr Hematol Oncol 2007;29:841-4.

15. Rao RN, Sinha S, Babu S, et al. Fine-needle aspiration cytology of primitive neuroectodermal tumor of the urinary bladder: a case report. Diagn Cytopathol 2011;39:924-6.

16. Sueyoshi R, Okawada M, Fujimura J, et al. Successful complete resection of Ewing sarcoma arising from the bladder in a 10-year-old boy after chemotherapy. Pediatr Surg Int 2014;30:965-9.

17. Tonyalı Ş, Yazıcı S, Yeşilırmak A, et al. The Ewing's Sarcoma Family of Tumors of Urinary Bladder: A Case Report and Review of the Literature. Balkan Med J 2016;33:462-6.

18. Zheng Y, Tan F, Wang L, et al. Primary primitive neuroectodermal tumor of the urinary bladder: a case report and literature review. Med Oncol 2011;28 Suppl 1:S388-91.

19. Fontaine C, Schots R, Braeckman J, et al. Long-term survival in an adult metastatic renal peripheral primitive neuroectodermal tumor (PPNET) with multimodality treatment including high-dose chemotherapy. Ann Oncol 1997;8:691-4.

20. Rodriguez-Galindo C, Marina NM, Fletcher BD, et al. Is primitive neuroectodermal tumor of the kidney a distinct entity? Cancer 1997;79:2243-50.

21. Smith LM, Adams RH, Brothman AR, et al. Peripheral primitive neuroectodermal tumor presenting with diffuse cutaneous involvement and 7;22 translocation. Med Pediatr Oncol 1998;30:357-63.

22. Sorensen PH, Lessnick SL, Lopez-Terrada D, et al. A second Ewing's sarcoma translocation, $\mathrm{t}(21 ; 22)$, fuses the EWS gene to another ETS-family transcription factor, ERG. Nat Genet 1994;6:146-51.

23. Grier HE, Krailo MD, Tarbell NJ, et al. Addition of ifosfamide and etoposide to standard chemotherapy for Ewing's sarcoma and primitive neuroectodermal tumor of bone. N Engl J Med 2003;348:694-701.

24. González I, Andreu EJ, Panizo A, et al. Imatinib inhibits proliferation of Ewing tumor cells mediated by the stem cell factor/KIT receptor pathway, and sensitizes cells to vincristine and doxorubicin-induced apoptosis. Clin Cancer Res 2004;10:751-61.

25. Parada D, Godoy A, Liuzzi F, et al. Primary Ewing's sarcoma/primitive neuroectodermal tumor of the kidney. An infrequent finding. Arch Esp Urol 2007;60:321-5.

26. Venkitaraman R, George MK, Ramanan SG, et al. A single institution experience of combined modality management of extra skeletal Ewings sarcoma. World J Surg Oncol 2007;5:3.
Cite this article as: $\mathrm{Wu} \mathrm{Y}$, Ji H, Zhang S, Zhang Y, Chu W, Mei Y, Niu W, Zhang B. Primary primitive neuroectodermal tumor of urinary bladder: a case report and literature review. Transl Cancer Res 2021;10(11):4997-5004. doi: 10.21037/tcr-21-864 